McNeill, L.C., Shillington, D.J., Carter, G.D.O., and the Expedition 381 Participants

Proceedings of the International Ocean Discovery Program Volume 381

publications.iodp.org

https://doi.org/10.14379/iodp.proc.381.107.2019

Check for updates

Contents

\title{
Data report: summary of XRF scanning on core sections, IODP Expedition $381^{1}$
}

1 Introduction

1 Methods

2 Results

L.C. McNeill, ${ }^{2}$ G. De Gelder, ${ }^{2}$ M.L. Machlus, ${ }^{2}$ N. Fabregas, ${ }^{3}$ C. Mahoney, ${ }^{2}$

S. Pechlivanidou, ${ }^{2}$ J. Seguin, ${ }^{2}$ R.L. Gawthorpe, ${ }^{2}$ D.J. Shillington, ${ }^{2}$ G.D.O. Carter, ${ }^{2}$

J.D. Everest, ${ }^{2}$ and the Expedition 381 Participants $^{2}$

Keywords: International Ocean Discovery Program, IODP, D/V Fugro Synergy, mission-specific platform, Expedition 381, Site M0078, Site M0079, Site M0080, Corinth rift, Gulf of Corinth, XRF, X-ray fluorescence, Alkyonides Gulf, Eastern Mediterranean Sea, Aegean Sea, continental rifting, extension, active rift, normal fault, earthquake, horst, fault growth, rift development, synrift stratigraphy, drainage evolution, surface processes, basin paleoenvironment, glacio-eustatic cycles, sea level, semi-isolated basin, marine basin, lacustrine, sediment flux, Quaternary, Pliocene, Miocene, carbon cycling, nutrient preservation, marine isotope stage

\section{Introduction}

IODP Expedition 381 was conducted to examine, at high resolution, the tectonic and sedimentary processes of the earliest phase of continental rifting and the role of climate and sea level change in these processes. Three sites were drilled within the Corinth Rift, central Greece: two sites in the main Gulf of Corinth basin (Sites M0078 and M0079) and a third site in the Alkyonides Gulf in the eastern rift (Site M0080). One of the primary aims of the expedition was to generate a high temporal resolution chronostratigraphy for the synrift section, in particular for the last $\sim 1 \mathrm{My}$. To assist with this aim and also contribute to investigations of the basin paleoenvironment, regional paleoclimate, and sedimentary geochemistry, a series of core sections were analyzed using X-ray fluorescence (XRF) core scanning. The cores were scanned at the Center for Marine Environmental Sciences (MARUM) facility at the University of Bremen (Germany). This phase of scanning focused on the expanded high-resolution section within Hole M0079A. In addition, the shallowest sections of Holes M0078A and M0078B were scanned (Holocene and/or latest Pleistocene). Along with these sections, a series of intervals were also specifically scanned at a higher resolution for (1) investigation of potential tephra layers (in Holes M0078A, M0078B, and M0080A) and (2) investigation of turbiditehomogenite layers that may have links to earthquake triggering (in Holes M0078B, M0079A, and M0080A). The data presented here are available as a shipboard data set.

\section{Methods}

For the primary scanned section of Hole M0079A (see Table T1), XRF core scanner data were collected every $2 \mathrm{~cm}$ downcore over a $1.2 \mathrm{~cm}^{2}$ area with a downcore slit size of $10 \mathrm{~mm}$ using generator settings of 10 and $30 \mathrm{kV}$, a current of $0.04 \mathrm{~mA}$ for the $10 \mathrm{kV}$ setting and $0.5 \mathrm{~mA}$ for $30 \mathrm{kV}$ setting, and a sampling time of $7 \mathrm{~s}$ directly at the split core surface of the archive half with XRF Core Scanner III (Avaatech Serial No. 12) at the MARUM-University of Bremen. The $30 \mathrm{kV}$ run was measured using a Pd thick filter (to lower the background noise). For the higher resolution primary scanned sections of Holes M0078A and M0078B, data were collected every $1 \mathrm{~cm}$ downcore, and for the intervals scanned for

Table T1. XRF scanned core sections, Expedition 381. In addition to these complete sections, additional core sections from all holes were scanned at $0.5 \mathrm{~cm}$ resolution for analysis of potential tephra layers (Holes M0078A, M0079A, and M0080A) and turbidite-homogenite layers (Holes M0078B, M0079A, and M0080A). Download table in CSV format.

\begin{tabular}{ccccccc}
\hline $\begin{array}{c}\text { Top hole, } \\
\text { core, section }\end{array}$ & $\begin{array}{c}\text { Base hole, } \\
\text { core, section }\end{array}$ & $\begin{array}{c}\text { Top } \\
\text { depth } \\
(\mathrm{mbsf})\end{array}$ & $\begin{array}{c}\text { Base } \\
\text { depth } \\
(\mathrm{mbsf})\end{array}$ & $\begin{array}{c}\text { Resolution } \\
\text { (measurement } \\
\text { spacing) }(\mathrm{cm})\end{array}$ & $\begin{array}{c}10 \mathrm{kV} \\
\text { run }\end{array}$ & $\begin{array}{c}30 \mathrm{kV} \\
\text { run }\end{array}$ \\
\hline $381-$ & & & & & & \\
M0078A-3H-2 & M0078A-11H-2 & 6.74 & 25.94 & 1 & $\mathrm{x}$ & $\mathrm{x}$ \\
M0078B-1P-1 & M0078B-14P-1 & 0.01 & 47.94 & 1 & $\mathrm{x}$ & $\mathrm{x}$ \\
M0079A-1P-1 & M0079A-163R-CC & 0.02 & 704.90 & 2 & $\mathrm{x}$ & $\mathrm{x}$ \\
\hline
\end{tabular}

\footnotetext{
${ }^{1}$ McNeill, L.C., De Gelder, G., Machlus, M.L., Fabregas, N., Mahoney, C., Pechlivanidou, S., Sequin, J., Gawthorpe, R.L., Shillington, D.J., Carter, G.D.O., Everest, J.D., and the Expedition 381 Participants, 2019. Data report: summary of XRF scanning on core sections, IODP Expedition 381. In McNeill, L.C., Shillington, D.J., Carter, G.D.O., and the Expedition 381 Participants, Corinth Active Rift Development. Proceedings of the International Ocean Discovery Program, 381: College Station, TX (International Ocean Discovery Program). https://doi.org/10.14379/iodp.proc.381.107.2019

${ }^{2}$ Expedition 381 Participants' affiliations.

${ }^{3}$ Department of Earth Science, University of Bergen, Norway

MS 381-107: Published 28 February 2019

This work is distributed under the Creative Commons Attribution 4.0 International (CC BY 4.0) license. (c) BY
} 
tephra and turbidite-homogenites, data were collected every $0.5 \mathrm{~cm}$ downcore. All other parameters remained the same.

The split core surface was covered with a $4 \mu \mathrm{m}$ thin SPEXCerti Prep Ultralene 1 foil to avoid contamination of the XRF measurement unit and desiccation of the sediment. Data were acquired using a SGX Sensortech silicon drift detector (Model SiriusSD D65133Be-INF with $133 \mathrm{eV}$ X-ray resolution), the Topaz-X highresolution digital multichannel analyzer (MCA), and an Oxford Instruments $100 \mathrm{~W}$ Neptune $\mathrm{x}$-ray tube with rhodium (Rh) target material. Raw data spectra were processed by the analysis of X-ray spectra using the Iterative Least square software (WIN AXIL) package from Canberra Eurisys.

\section{Results}

The primary sections scanned from Hole M0079A and the upper parts of Holes M0078A and M0078B are presented in Table T1. All preliminary data (these primary sections and the additional intervals for tephra and turbidite-homogenite layers) are available at the Scientific Earth Drilling Information Service (SEDIS; http://sedis.iodp.org) and at http://iodp.pangaea.de. 